\title{
"Abusers of Themselves with Mankind": On the Constitutive Necessity of Abuse in Evangelical Sex Manuals
}

\author{
William P. Boyce
}

Citation: Boyce, William P.. 2021.

"Abusers of Themselves with Mankind": On the Constitutive Necessity of Abuse in Evangelical Sex Manuals. Religions 12: 119. https:// doi.org/10.3390/rel12020119

Academic Editors: Randall Balmer and Edward Blum

Received: 2 December 2020

Accepted: 10 February 2021

Published: 13 February 2021

Publisher's Note: MDPI stays neutral with regard to jurisdictional claims in published maps and institutional affiliations.

Copyright: (c) 2021 by the author. Licensee MDPI, Basel, Switzerland This article is an open access article distributed under the terms and conditions of the Creative Commons Attribution (CC BY) license (https:// creativecommons.org/licenses/by/ $4.0 /)$
Department of Religious Studies, University of Virginia, Charlottesville, VA 22911, USA; wpb5jd@virginia.edu

\begin{abstract}
In this essay, I recount the recent narrative of an evangelical awakening on issues of sexual violence though the impact of Rachael Denhollander, an advocate and survivor of sexual trauma. Denhollander's evangelical credentials authorized fellow US evangelicals to sympathize with the \#MeToo movement. I then show how this script of awakening obscures a long history of abuse in relation to LGBTQ persons of faith. I demonstrate how American evangelical sex manuals make abuse both constitutive to a genuine discovery of personhood and simultaneously marginal to one's self-identification. Paradox becomes a framework for describing the "problem" of homosexuality in evangelical circles. Finally, I reflect on what it suggests to scholars of religion that a religious community ensconces abuse in this distinctive way.
\end{abstract}

Keywords: evangelicalism; abuse; trauma; LGBTQ; homosexuality; queer; queerness; theology; \#MeToo; \#evangelical; American evangelicalism; sexual violence

\section{Introduction}

Evangelical Christians are finally waking up to the horror and reality of sexual violence in their midst-or so goes a pervasive cultural script in circulation today among insiders and outsiders of US evangelicalism. In the age of \#MeToo and \#ChurchToo, the reasons are urgent and profound for heralding this script and acknowledging the core of its message. ${ }^{1}$ The compelling story of a sudden awakening inside the ranks of American evangelicalism, however, elides an important detail. The elision is less innocuous than it may seem. In fact, it relates to the long, contradictory work of stifling LGBTQ persons of faith. For many evangelical queers, abuse is hardly a new word. Their experiences within the evangelical community in the United States belie the dominant narrative of an abrupt, ghastly, great awakening to trauma and abuse. The closeted history of evangelical queers is one marked by abuse-a category which has functioned as a constitutive touchstone for the construction of queer sexual identities as enjoined by US evangelicalism.

In this essay, I first recount the dominant narrative of an evangelical awakening on issues of sexual harm and bodily violation though the impact of Rachael Denhollander. Denhollander was the former Michigan State University gymnast turned sexual assault advocate who confronted her abuser, Larry Nassar, in 2018. The spirit of her testimony and the character of her evangelical credentials authorized fellow US evangelicals to sympathize with the \#MeToo movement. More precisely, evangelical congregants expressed cautious reception to specific elements of the \#MeToo phenomenon, guided by Denhollander's iconic witness as a survivor, advocate, and faithful Christian. Then, I show how this script of sudden awakening obscures a longstanding history of abuse in relation to evangelical queers. I demonstrate how American evangelical sex manuals make abuse both constitutive to a genuine discovery of personhood and simultaneously marginal to one's self-identification. Paradox becomes the framework for describing the centralized and decentralized "problem" of homosexuality in evangelical circles. Finally, I reflect on

1 For a helpful overview of both campaigns, see (Colwell and Johnson 2020). 
what it suggests for a religious community to ensconce abuse in this distinctive way. What does it mean for abuse to take on a seemingly positive valence in becoming a skeleton key for unlocking the deep mystery of the sensual self? This stubborn mythology, although deeply problematic, can prove generative for the lived experiences of queers in their own sexual awakenings.

Hereafter, I distinguish between two types, namely abuse and abuse* ${ }^{2}$ The former entails any direct or indirect physical, sexual, and/or verbal maltreatment or any psychological coercion related to the same. ${ }^{3}$ The latter incorporates the former definition but adds another layer: an ideological conception of harm that can be fitted retroactively onto any set of circumstances. On this account, abuse* can be used to describe thoughts, actions, affects, or presences that bear no resemblance to abuse. ${ }^{4}$ As I explain in the second half of the essay, the latter category of abuse* is conceptually slippery on purpose. US evangelical authorities, as I explore below, leverage this slippage to diagnose queer sexuality. American evangelical Christians interpret so-called divergent lifestyles and their origins by associating queer sexualities with abuse*, despite its lack of any consistent or coherent definition.

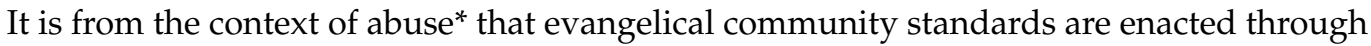
the diagnosis and treatment of queerness. By instilling these community sexual norms, US evangelicalism forms and malforms queers to be, as the King James Bible translates it and as my title alludes, "abusers of themselves with mankind." 5

\section{The Dominant Narrative}

On 24 January 2018, during the sentencing hearing of Rachael Denhollander's sexual assailant - the former US Gymnastics and Michigan State University doctor, Larry Nassar-Denhollander raised a hauntingly simple question: "How much is a little girl worth?" As the first person to report publicly the molestation to law enforcement and the last to provide an impact statement alongside 155 fellow victims, Denhollander's confrontation of her serial predator was a powerful expression of the collective voice (Levenson 2018). Despite being shattered by sexual violation, manipulative control, and systemic silence, she reclaimed her stolen voice for the sake of countless survivors. She refused to sterilize the horror of her injuries, and she demanded justice in the face of heinous crimes. Her statement received a standing ovation from the courtroom and quickly went viral online (Macur 2018).

The ardent resolve of Denhollander's literal and symbolic reclamation led to her placement on the TIME 100 Most Influential People of 2018 (Raisman 2018). However, it was her cry for healing and her extension of forgiveness in light of her suffering that left the evangelical world in awe of her bravery. A self-identifying evangelical, Denhollander invoked the rhetoric of God's judgment, grace, and redemption in a manner consonant with the theological and communal expectations of American evangelicalism (CNN 2018). As a result, she was immediately elevated within the US evangelical subculture as a trusted authority. 6

The elevation of Denhollander, however, was not without consequence. US evangelical Christians soon learned that they were not thereby immune from Denhollander's critique of abuse, enablement, stigmatization, and the corrupting systems they sustain. One week

2 I am using the asterisk to imply the functional activity of category defiance, as a purposeful echo of the work that "trans ${ }^{* \prime}$ can do (e.g., transing), in addition to and beyond the identitarian function; see (Strassfeld 2018).

3 This definition is my own idiosyncratic amalgamation, but it draws principally from the Centers for Disease Control and Prevention, while spot-checking other relevant health and advocacy resources.

4 As an aside, the legal history of "gay panic" or "trans* panic" defenses in the judicial system is an interesting secular analogue; gay or trans* bodies are positioned as bare facts that are said to mitigate culpability of violence or to justify violence, even murder; here, non-threatening encounters are fitted as threatening encounters under the apparatus of the law; see (Strader et al. 2015).

51 Cor. 6:9 (King James Version)

6 Denhollander's catapult to prominence was made possible in part by previous generations of evangelical women who navigated positions of authority and leadership while upholding cultural-theological expectations surrounding evangelical femininity, particularly the boundaries of gendered difference and sexual probity as an asymmetrical responsibility for women; for more on this negotiated dynamic of female agency within American evangelicalism, see (Johnson 2019). 
after the sentencing statement went viral, Denhollander was interviewed by the flagship evangelical magazine Christianity Today. During the interview, Denhollander reproached evangelicals for "gloss[ing] over the devastation of any kind of suffering but especially sexual assault, with Christian platitudes like God works all things together for good or God is sovereign" (Lee 2018). Beyond these rhetorical and discursive interventions, Denhollander rebuked the evangelical church for producing unsafe environments and deformative contexts for disclosing assault and trauma. Denhollander lamented, "Church is one of the least safe places to acknowledge abuse because the way it is counseled is, more often than not, damaging to the victim" (ibid.). The deficiency or nonexistence of basic traumainformed principles, she insisted, compounded the effects experienced by victims who place their faith in church leaders. She added, "There is an abhorrent lack of knowledge for the damage and devastation that sexual assault brings. It is with deep regret that I say the church is one of the worst places to go for help .... There are very, very few who ever found true help [for sexual trauma and abuse] in the church" (ibid.).

Cutting to the heart of the matter, Denhollander identified specific leaders in American evangelicalism who were forsaking their pastoral duties. Her insights, if startling, were borne of her own experiences. Previous to her courtroom presentation, Denhollander had been involved in small-scale advocacy for survivors of assault at her local Reformed Baptist church in Louisville, Kentucky. To her dismay, Immanuel Baptist of Louisville had decided to facilitate the restoration to ministry of pastor CJ Mahaney. ${ }^{7}$ Mahaney was the head pastor and former president of Sovereign Grace Ministries (SGM), a denominational network formerly based in Maryland. SGM had relocated to Louisville after a series of conspicuous allegations of impropriety converged just prior to the \#MeToo reckoning. Despite the move by Mahaney and a devoted cadre, ongoing allegations of conspiracy and extensive cover-ups of sexual assault within the SGM network had followed them. Nevertheless, all signs appeared to point in the direction of Mahaney weathering the headwinds. As an influential, well-connected US evangelical thought leader, Mahaney had retained broad evangelical support from the movement and its key figures during this turbulent period (Stanley 2016).

Denhollander had raised her objections to the pastoral team at Immanuel Baptist out of concern for other survivors in the pews. She opposed Mahaney's restoration to full ministry and her church's decision to permit him to fill their pulpit as a frequent guest. Her opposition was acute given the conviction of Nathaniel Morales, a former youth pastor at Mahaney's congregation in Maryland (Johnston 2018). Morales had been arrested and sentenced to forty years in prison after being convicted of decades of sexual predation of male minors (Bailey 2014; Morse 2014). Denhollander had been firm yet discreet about her resistance to Mahaney's presence in and blessing by Immanuel Baptist. The fact of her pushback, however, was enough to lead the pastoral team to propose that she relocate to another place of worship. Eventually, the impasse resulted in a "voluntary" separation from her local church (Immanuel Baptist 2018).

For Denhollander, the message was clear. "My advocacy for sexual assault victims, something I cherished, cost me my church," she recalled in her original victim impact statement (CNN 2018). ${ }^{8}$ It is worth noticing that Denhollander's criticism of her church's handling of the situation was not only well-founded. It was also muted by her display of discretion. Her unwillingness to identify and shame her church by name-as in, her refusal to "lord the situation over them" - reinforced familiar expectations about female submission in evangelicalism (Piper and Grudem 1991; Griffith 2000). Denhollander's

7 Pastor Ryan Fullerton of Immanuel Baptist and CJ Mahaney of Sovereign Grace Ministries were also connected through two popular and influential evangelical networks: 9Marks, based in Washington, DC, and The Gospel Coalition. Both networks host conferences, maintain interactive websites, publish Christian texts, and provide resources for evangelical churches and leaders, typically with non-denominational and reformed theological tendencies.

8 Emphasis added to highlight the anonymized nature of Denhollander's condemnation of her faith community; by satisfying common evangelical expectations of respectful and demurring women, she signaled to her fellow evangelicals her insider status, her godly femininity and womanhood, and her trustworthiness. 
respectful demur, so to speak, was exactly the posture that had ingratiated her among American evangelicals. It was even praised by Immanuel Baptist in an ensuing apology that later outed them as Denhollander's church. Immanuel Baptist's public apology was nonetheless faltering and revealed the troubling pattern of chilling practices in US evangelicalism. "Fortunately," they wrote, "because of Rachael's decision not to name our church publicly, we were able to enter into a season of deep self-examination without the scrutiny of the outside world" (Immanuel Baptist 2018). Far from a survivor-centered approach, the apology seemed to reimpose the old protocols of silence, submission, selfcontainment, and self-sacrifice.

During her interview with Christianity Today, Denhollander was less muted. She warned US evangelicals about underwriting their support of specific figures, networks, and institutions by means of willful blindness on matters of sexual assault. The scope of the problem had become obvious. Denhollander addressed the subtext of Immanuel Baptist's imprimatur of CJ Mahaney, the implications of American evangelicalism's confidence in the not-quite-disgraced megachurch pastor, and the open hypocrisy that this had exposed:

"The ultimate reality that I live with is that if my abuser had been Nathaniel Morales instead of Larry Nassar, if my enabler had been [an SGM pastor] instead of [Michigan State gymnastics coach] Kathie Klages, if the organization I was speaking out against was Sovereign Grace under the leadership of [Mahaney] instead of MSU under the leadership of Lou Anna Simon, I would not only not have evangelical support, I would be actively vilified and lied about by every single evangelical leader out there. The only reason I am able to have the support of these leaders now is because I am speaking out against an organization not within their community. Had I been so unfortunate so as to have been victimized by someone in their community, someone in the Sovereign Grace network, I would not only not have their support, I would be massively shunned. That's the reality" . (Lee 2018)

It should be intolerable to evangelicals of conscience, averred Denhollander, to praise those who speak the truth of God's word with absolute insistence and clarity to those outside the camp while shrinking from the same inside the camp. In the face of this double standard, she stipulated, nothing short of radical transformation would do. An awakening would be necessary, especially where logics of quiet, redemptive suffering colluded with conspiracies of silence to protect US evangelical leaders in positions of power. Scrutiny was of the essence. ${ }^{10}$

In the months that followed her courtroom witness, and in the wake of her exhortation to the American evangelical community, Denhollander became an icon for a series of "holy rumblings" inside church spaces (Shellnutt 2019). In rapid succession, debts were coming due from the many corners of US evangelicalism. In March of 2018, CJ Mahaney withdrew from the prominent Together for the Gospel (T4G) evangelical conference set for April. Mahaney denied that his withdrawal was an admission of guilt or awareness. He contended that his sole desire was to avoid scandal and distraction of the gospel, but his luster was wearing thin (Shellnutt 2018a). In April of 2018, Bill Hybels of Willow Creek Community Church resigned his head pastorate position and board membership at the megachurch he had founded in Chicago in 1975. After digging in against "collusion" and "false accusations" of sexual misconduct, Hybels ultimately lost the confidence of innumerable evangelical defenders and was forced out (Smietana 2018a, 2018b, 2018d).

In May of 2018, Paige Patterson, the president of Southwestern Baptist Theological Seminary (SWBTS) and the architect of the conservative resurgence within the Southern Baptist Convention (SBC), was fired by unanimous agreement of the SWBTS Board of Trustees. He was subsequently stripped of his retirement benefits and privileges. Patterson stood accused of lying to the board about two scenarios: he had counseled a domestic abuse survivor to return to her abusive spouse and had attempted to "break ... down" a female

10 Mahaney and SGM disputed the allegations; see (Sovereign Grace 2019). 
student who had intended to report a sexual assault at Patterson's previous institution, Southeastern Baptist Theological Seminary (Shellnutt 2018b, 2018c). The holy rumblings continued as influential stakeholders added their voices. Southern Baptist author and speaker Beth Moore took the unprecedented step of writing a widely disseminated open letter to the male leaders and pastors of the SBC. Moore corroborated the fact of the existence of toxic environments and toxic elements in the SBC-itself a radical intervention to many observers. She shared her first- and second-hand knowledge of sexual harassment, assault, and sexism in the church, and she adjured her denomination to walk the difficult road of godly repentance (Moore 2018).

Entrenchment and counter-messaging occurred. Nonetheless, the distance between two distinct standing ovations within the US evangelical subculture underscores the scale of the transformation in progress. In January of 2018, megachurch pastor Andy Savage admitted to a "sexual incident" before his Memphis congregation. The members rose from their seats to applaud his bold "confession," enacting something like a collective rite of redemption (Stetzer 2018; Woodson 2018). ${ }^{11}$ By October of 2019, it was Denhollander who was being greeted with enthusiastic applause. At a Dallas conference of 1600 preachers, leaders, and laity organized by the SBC's Ethics and Religious Liberty Commission, Denhollander insisted, "you are the voices to stand for these survivors." Justice would require resolute action, she testified. To a standing ovation, Denhollander closed by urging members of the SBC to courageously "stand up and fight" (Denhollander 2019).

Change was dawning on the horizon. Evangelical churches, denominations, and institutions across the country began to embrace the \#MeToo and \#ChurchToo awakening with tangible outputs. US evangelicals were being shepherded by the spiritual example of Rachael Denhollander. New policies, new training initiatives, new reporting structures, new accountability mechanisms, and new forms of contrition blossomed across the country.

The non-evangelical world also participated in the same narratival unfolding. Investigative journalists wrote lengthy pieces on sexual assault, abuse, and cover-ups in US evangelical churches. The Houston Chronicle released an in-depth six-part "Abuse of Faith" series on extensive transgressions in the Southern Baptist Convention, incorporating a searchable database of SBC members and church officials convicted of crimes of sexual violence (Tedesco et al. 2019). "The SBC Has a Sex-Abuse Problem," wrote the Wall Street Journal (Ault 2019). Eliza Griswold of the New Yorker detailed the lives of evangelical women who celebrated the \#ChurchToo movement, even as they quibbled with its "exvangelical" origins (Griswold 2018). In his piece for the Washington Post, "The Sin of Silence: The Epidemic of Denial about Sexual Abuse in the Evangelical Church," Joshua Pearse charted widespread abuse and concealment in evangelicalism. He delineated a variety of contributing factors, including "authoritarian leadership, twisted theology, institutional protection, obliviousness about the problem and, perhaps most shocking, a diminishment of the trauma sexual abuse creates-especially surprising in a church culture that believes strongly in the sanctity of sex" (Pearse 2018). Each story and exposé tracked the novel and agonizing awakening in the evangelical subculture throughout the United States. All parties seemed to agree: an overwhelming, unmistakable, and altogether unprecedented evangelical reckoning had arrived in North America.

\section{Queer Abuse* as the Underside of the Dominant Narrative}

The dominant narrative outlined above is a welcome development in the US evangelical subculture for a host of appreciable reasons (Gerson 2018). Indeed, North American evangelicals are coming to terms in major ways with the gravity of sexual violence and the horror of bodily harm. ${ }^{12}$ However, the conceit of abuse as a radically new phenomenon on the US evangelical radar is misleading.

11 Andy Savage later faced an internal investigation at his church, resigned his position as teaching pastor, and launched another church in Memphis less than two years later; see (Relevant Staff 2019).

12 For a fascinating survey of pastoral attitudes, practices, and reflections in the wake of \#MeToo, see (Smietana 2018c). 
The notion of abuse as an unconscionably negative and destructive experience is only half of the story that American evangelicalism has told itself. Queers of faith know something of the underside of this tale. From the underside, theologies of redemptive trauma are not being reevaluated as misapplications of scriptural principles; instead, they are being reinforced as life-affirming scriptural mandates. The failure to rectify the elision in the dominant narrative, wittingly or unwittingly, amounts to complicity in the attenuation of queer stories within American evangelicalism. In order to expose this narratival elision, I will turn to two popular US evangelical Christian sex manuals from "The Every Man Series." Doing so will reveal how the category of abuse* operates as a positive and inescapably core reality on the underside of the narrative. It will also reveal just how recently this conceptual category was still deemed a legitimate option in American evangelicalism for understanding queerness. (In truth, this alternative rendering of abuse* is still operative in too many segments of American religious and cultural life.) This section will demonstrate how unlikely it was-and is - that the dominant narrative came to represent the whole story of evangelical trauma in the United States.

\section{1. "The Every Man Series" and Purity Culture Theology}

"The Every Man Series" is the joint production of author Stephen Arterburn and his various co-authors, principally Fred Stoeker and Shannon Ethridge. The premise of the series is that "sexual integrity" is a vital discipline of Christian faithfulness. ${ }^{13}$ And, it would seem, sexual integrity is good for business. ${ }^{14}$ The series comprises thirty individual titles, ministry workbooks, and daily devotional texts. ${ }^{15}$ According to WaterBook Press, an imprint of Penguin Random House Publishing, over four million books from the series have been sold to date. The series titles Every Young Man's Battle (2002), Preparing Your Son for Every Young Man's Battle (2003), and Every Young Woman's Battle (2004) each received Gold Medallion Book Awards from the Evangelical Christian Publishers Association (ECPA), having fulfilled the eligibility requirements by selling over five hundred thousand copies, respectively. ${ }^{16}$

"The Every Man Series" echoes the same American evangelical purity culture it simultaneously constructs. As artifacts of purity culture theology, the books in the series endorse particular gender typologies and prioritize certain imperatives around sex. Purity culture norms are ratified throughout the text of the series, but consider how they are advertised on the back-covers in bold fonts: "How can any young man remain pure in the real world of sexual temptation?" (Every Young Man's Battle) and "Guys aren't the only ones fighting a battle for purity" (Every Young Woman's Battle).

Following Amy DeRogatis' work on evangelical sex manuals, I argue that "The Every Man Series" galvanizes American evangelical purity culture by resisting and transfiguring its surroundings (e.g., a putatively secularized, libertine society). In evangelical sex manuals like those of "The Every Man Series," the catalyst for moral and cultural renewal hinges upon intimate disclosures and personal confessions of sin. As DeRogatis points out, in these manuals, the pursuit of individual piety and purity frees the power of the Spirit for wider cultural resistance and transfiguration; therefore, "[d]esires are examined, acts are regulated, and bodies are testimonial sites" (DeRogatis 2015, p. 8). "The Every Man Series" reinforces the individual, communal, and global stakes of purity culture. Against the backdrop of an American culture supposedly rife with sexual temptation and sin, the

13 Although "sexual integrity" is by no means a conceptual innovation of the series, it is a term repeatedly used by the authors, as in subtitles, and reflects much of the purity culture language it projects. For more on purity culture, see (Gardner 2011; Moslener 2015).

14 As of September 2020, Every Young Man's Battle was \#4 on Amazon's “Teen \& Young Adult Dating," \#17 on “Christian Men's Issues," and \#21 on "Christian Dating \& Relationships"; Every Young Woman's Battle was \#8 on Amazon's "Teen \& Young Adult Dating."

15 Arterburn even narrated a "captivating, informative docudrama," based on the "hard-hitting truth" of the eponymous book, called Every Young Man's Battle (Arterburn 2003).

16 References to the success and awards of books can be found on Waterbrook Multnomah's website (https://waterbrookmultnomah.com/books/60 6865/every-mans-battle-revised-and-updated-20th-anniversary-edition-by-stephen-arterburn-and-fred-stoeker-with-mike-yorkey/[accessed on 1 December 2020]); and the list of Gold Medallion Book Award Finalists, renamed the Christian Book Awards, can be found at https:// christianbookexpo.com/bookawards/ (accessed on 1 December 2020). 
series offers relevant and relatable resources for evangelical Christians, specifically youths, navigating the "proper use of sexual bodies", as limned by Scripture (ibid., p. 3).

In accordance with purity culture theology, "The Every Man Series" sanctions evangelical heterosexuality in unequivocal terms. The books in the series use a mixture of everyday prose, casual storytelling, and spiritual vernacular to affirm heterosexuality. Every Young Man's Battle and Every Young Woman's Battle go a step further. What else could be needful in the resistance and transfiguration of the contemporary moment? In response to a shifting culture, both sex manuals tackle the "issue" of homosexuality. Unlike some evangelical sex manuals, which treat the topic as utterly taboo, the authors of Every Young Man's Battle and Every Young Woman's Battle decline to transpose the "issue" onto the blank margins of the text. Instead, they opt to address the matter directly, even though it expresses a serious challenge to the purity culture framework of American evangelicalism. The uneasy inclusion of homosexuality is increasingly common in popular evangelical purity manuals-for example, by John and Stasi Eldridge (Eldridge 2001; Eldridge and Eldridge 2005), Dobson (2001, 2010), and Timothy and Kathy Keller (Keller and Keller 2011). In these evangelical sex manuals, same-sex eroticism is portrayed as incompatible with the fixed commitments of sexual integrity and Christian faithfulness. It is regularly associated with traumatic origins that unlock the gateway to recovery. Often, the topic is broached with a self-articulated concern for the sake of their readers and their readers' standing before God.

\subsection{Tracing the Structure, Arguments, and Paradox of Queer Abuse*}

First and foremost, with respect to Every Young Man's Battle and Every Young Woman's Battle, the layout is itself instructive. Consider the design format of each manual in relation to the discussion of queer sexuality. In Every Young Man's Battle, twenty-three chapters are organized under seven parts. Chapter Twenty-three constitutes the standalone and synonymous Part Seven. This final section is titled, "A Further Important Discussion: When Your Feelings Are for Other Guys." The authors invite the question of the reader's potential "same-sex attraction," or how his "feelings" create an experiential lens for approaching the overall content of the text (Arterburn and Stoeker 2002, p. 223). In Every Young Woman's Battle, twenty-five chapters are arranged under seven parts along with a concluding postscript. Technically, the equivalent section on homosexuality in Every Young Woman's Battle is neither enumerated as one of the chapters nor listed under one of the seven parts. Instead, the autonomous unit is classified and positioned merely as an "Afterword" (Arterburn and Ethridge 2004, p. 219). It is unclear whether the corresponding title, "If You Desire Other Women," is intended to insinuate a higher degree of conditionality in female homosexuality when compared to male counterparts. Personal application is similarly advised. Both sections on homosexuality, whether as a final chapter or epilogue, are discretely partitioned from the main body of the text. Thematic segmentation works to convey here the import of boundary-keeping when assessing the theological and therapeutic other of queer sexuality. Put another way, the structural distinction in format communicates the position of difference among persons.

The authors of both evangelical sex manuals present homosexuality as a path-dependent condition of abuse*. In both texts, abuse functions as an etiological explanation for samesex orientations, and yet abuse* has no consistent definition. Sometimes, the connotation of abuse* is literal, as in bodily sexual violence. Every Young Man's Battle states, "You may have been molested when you were younger, and that started the feelings. Even though it was abuse, you couldn't figure out why it made you feel the way you did" (Arterburn and Stoeker 2002, p. 223). Likewise, in Every Young Woman's Battle, the authors suggest, "perhaps your father or another man sexually abused you, and so you have negative feelings toward men and feel you can't trust them" (Arterburn and Ethridge 2004, p. 220). However, less literally, the term also seems to imply dysfunctional family systems, childhood trauma, and/or socio-cultural stimulants (e.g., exposure to specific media, celebrities, events, hobbies, activities, authority figures, lessons, or materials). Episodes that might qualify include 
watching "Madonna and Britney Spears's bold display of passionate kissing on national television" (ibid., p. 220) or knowing "boys your age may not have connected with you" (Arterburn and Stoeker 2002, p. 224). At times, abuse* simply means the diminution or, conversely, the amplification of some feeling of inadequacy, loneliness, vulnerability, security, intimacy, sensitivity, or appreciation.

The slippage is intentional and pedagogical. Abuse* becomes a freighted concept in both of the evangelical sex manuals, with seemingly unlimited explanatory power. The reader, as an interested observer or as the subject of the material, is encouraged to depict abuse $^{*}$ retrospectively as an explanation for the presence of gay or lesbian desires. Again, the depiction of abuse* to explain the origins of queer sensuality holds even in circumstances where no abuse has occurred. For instance, the abuse* of having a withdrawing father can induce queer desires (ibid.). So too the abuse* of being cherished too dearly by a mother can elicit homosexuality (Arterburn and Ethridge 2004, p. 220). Likewise, the abuse* of an aggressive football coach, a billboard with "scantily clad women," or school curricula mentioning "'two mommies' or 'two daddies'" might hold the key (ibid., pp. 220-21).

In both of the American evangelical sex manuals, the rationale for the origins of same-sex desire is anchored in abuse*. At least in these texts, there would appear to be a distinct intensity in the relationship between trauma and queerness that is less evident in discussions of other kinds of temptations or sins. This rationale validates and peddles old tropes within US evangelical treatments of homosexuality, which link pedophilia and incest with the birth of queer desire. ${ }^{17}$ Notably, however, the authors of both of the texts recalibrate the timeworn paradigm. Unlike the old discursive regimes that fixated on homosexuals as traumatizing predators, the new therapeutic regimes are shifting attention to homosexuals as traumatized victims, which the authors of Every Young Man's Battle and Every Young Woman's Battle support. ${ }^{18}$ Both of the evangelical sex manuals discipline their readers to supplant an overriding fear of the predator/abuser with an evangelical "love" for the victim/abused*. This is not to say the former is fictitious and the latter altogether innocent, but rather that in these texts, the victim/abused* is worthy of God's transformative love. In other words, these two manuals from "The Every Man Series" center the victim of abuse* for deliberate pastoral and therapeutic care-albeit problematically so-rather than focusing on the perpetrator of abuse* in judgment and opprobrium. The attempt to reframe queer abuse* positively as an opportunity for the reordering love, righteousness, and empowerment with God's grace is, to borrow a phrase from Melissa Hackman, an example of "desire work" (Hackman 2018, p. 7).

The process of centering the victim in accordance with these sex manuals seems to make abuse* an occasion for the genuine discovery of personhood. This is done in at least four ways. First, the sheer fact of the concluding units on homosexuality is noteworthy, in and of itself. The inclusion of these topics is not insignificant in terms of providing some manner of representation of queerness in American evangelical sex manuals. ${ }^{19}$ Second, the corresponding sections on homosexuality promote a personalized encounter with the materials presented in the texts and emphasize self-interrogation. Third, the moral urgency of this self-interrogation is coupled with a posture of compassion. For example, "while you didn't choose to have the feelings you have, you can choose what to do with them" (Arterburn and Stoeker 2002, p. 226). Because the evangelical sex manuals feature the victimhood of abuse ${ }^{*}$ as the foundational paradigm for bracketing queer sexuality, the reader is purposefully steered toward an empathetic reaction, whether for themselves or for others as victims of abuse*. Fourth, both of the texts commend self-disclosure as the culmination of this process of compassionate introspection. Like so many sexual abuse

17 For more on Christian discourse about homosexuality, see (Viefhues-Bailey 2010); for a primary text indicative of these associations, see (Satinover 1996).

18 For more on the relationship between American Christianity and therapeutic responses to homosexuality, see (White 2015).

19 Again, whether this representation is accurate or inaccurate, it nonetheless gives name to a reality left under erasure in much of US evangelical theological, pastoral, and therapeutic discourse. 
survivors, the journey from silence, invisibility, confusion, and shame to acknowledgement, visibility, awareness, and fortitude is profound. Feeling grounded and safe can build a pathway to resilience. The ability to name one's own experience of abuse is fueled by courage and compassion; it can create a newfound sense of self and self-empowerment. ${ }^{20}$ Every Young Man's Battle and Every Young Woman's Battle trade on this same journey of transformation around abuse* as desire work.

Broadly speaking, the transformational journey espoused by both of the evangelical sex manuals is theologically schematized. It follows the proverbial straight and narrow pathway counseled by an evangelical interpretation of Scripture. ${ }^{21}$ In both texts, the journey of transformation around abuse* involves "godly" diagnosis, therapeutic examination, and restoration or rebirth for persons with queer desires. It entails the transformative healing of abuse* as well as the supposed by-product of abuse*, i.e., queerness. The pathway of confession and redemptive resilience is theologically assured for the new man or woman of God. However, the practical aspects of the transformational journey designated by the sex manuals are elusive. Is it possible to overcome abuse* by eradicating queer desire in this life, and to do so permanently? Is it imperative to remember the abuse* that spawned those desires in order to remain battle ready in the spiritual warfare against the flesh and sinful temptations? If one gives into temptation and experiences a lapse, does it suggest the original root trauma was insufficiently confronted or was it incorrectly identified? Are all homosocial thoughts and interactions equally dangerous? Does renewal involve the total subjugation of queer desires or the replacement of queer desires with straight desires?

Tethering abuse ${ }^{*}$ to sensuality in this schema has innumerable deleterious consequences. That said, the logic of this association is productive. The disciplinary power and productivity of abuse* that emerges from Every Young Man's Battle and Every Young Woman's Battle contributes to the underside of the dominant narrative. After all, per both texts, if queer desire exists, then abuse* is the proper basis for filtering the entirety of one's life experiences and disciplining oneself as an erotic subject. For readers of the evangelical sex manuals, abuse* operates as a necessary and constitutive element in coming to terms with queer desire, even for the purpose of eventual eradication. As the authors of the texts aver, "the attraction is there. You didn't choose to be attracted to men, but you are ... . We want to help you understand why you feel the way you do and provide some help for you" (Arterburn and Stoeker 2002, p. 223). At least one salubrious consequence flows from the association of queerness and abuse* in the sex manuals from "The Every Man Series." Merely by bringing to light the conditions of possibility for an emergent queerness, a psycho-spiritual on-ramp to queer existence is established within American evangelical discourse. The potential for the discovery of an unapologetic queer identity is thus intimated by this association, despite itself, for some readers. ${ }^{22}$ If momentarily, queerness becomes cognizable and recognizable-albeit shaped through the prism of abuse*.

In Every Young Man's and Every Young Woman's Battle, the authors center the victim of abuse* in their review of homosexuality. Queer desire is the symptom of abuse*, and

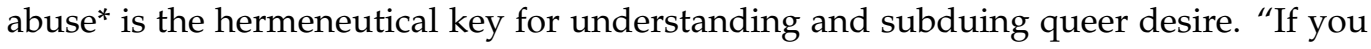
had a mother or female caretaker who was unhealthy and either smothered you out of her own selfishness or was cruel to you out of her own depravity," the authors advise, "it would interrupt the development of an attraction to women .... The foundation made you an easy target if you were approached by other men" (ibid., p. 225). The process of centering that is delineated by these evangelical sex manuals is not only problematic; it is also paradoxical. ${ }^{23}$ The process of centering that is urged in both of these texts

20 For more on the relationship between traumatic experiences and healing, see (Jones 2009).

21 For some discussion of Biblical inerrancy and debates on homosexuality in evangelicalism, see (Rogers 2006; Gagnon 2001).

22 For more on the relationship between queerness and apologetics, see (Tonstad 2018).

23 Paradox is a useful way of capturing this ongoing dynamic of investment and divestment, although I do not mean to imply a formal philosophical or logical category. Evangelical sex manuals might be more inclined to describe this dynamic as "living in the tension" of Christian sanctification, or the pursuit of holiness, or the struggle for victorious living, or the war between the spirit and the flesh-a dynamic that leaves room for resolution in this life or the life to come. 
simultaneously requires a process of decentering. These American evangelical sex manuals render abuse* to be an inescapable core reality about personhood for those with queer desires; contemporaneously, they render abuse* to be non-essential and non-determinative for the character, aim, and direction of the Christian life. For both texts, dealing with abuse* is deemed an essential life mission to be undertaken by persons with queer desires. At the same time, it is deemed an impermanent project for persons with queer desires who faithfully expect the evanescence, abatement, or vanquishment of queer desire.

The paradoxical framework of centering and decentering is productive in formative and malformative ways; it is also delicate. Readers who encounter the concluding units that review homosexuality in the sex manuals are promised that "Change Is Possible," as one subheading declares. ${ }^{24}$ The authors of "The Every Man Series" seek to reassure their American evangelical readers of what hangs in the balance. Consider two passages that delicately balance the centering and decentering of abuse*. "If these things ring true of your life," the authors of Every Young Man's Battle assert, "you're one of thousands of confused and searching men who long to know what's normal and how to experience it. This is where your choices come in, because there's so much hope for you, if you choose it" (ibid., p. 225). The authors of Every Young Woman's Battle proclaim, "you are not powerless to develop different, more healthy desires ... hundreds of former gay and lesbian individuals have left their homosexual lifestyles and found wholeness in their newfound heterosexuality" (Arterburn and Ethridge 2004, p. 220). The messages of self-empowerment trade, paradoxically and problematically, on messages of self-marginalization. One might even describe the process as self-annihilative.

The balancing act represented in these evangelical sex manuals betrays a specific anxiety about the paradoxical framework of abuse*. In the process of centering their own experiences as victims of abuse ${ }^{*}$, persons with queer desires might be tempted to embrace those desires too thoroughly at some point in time, the authors of these texts worry. The authors prescribe a concomitant process of decentering as a remedy. "Remember to guard not just your body, but your mind and heart as well ... . There is no shame in running from sin" (ibid., p. 222). The decentering process labors to prevent the victim of abuse* from aligning too nearly with their own abuse* and the supposed consequences thereof, namely queerness. "The world will tell you that you must act on your feelings-sexualize them - and only then will you feel whole .... You can listen to the world, or you can hear another voice that appears fainter but grows stronger everyday [sic]" (Arterburn and Stoeker 2002, p. 225). Both texts caution against such a close alignment of identification. Any attempt at centering the story of abuse* must also function synchronously to decenter the same narrative. Do not tarry with sin or temptation, they attest, even if it is a fundamental point of contact for self-realization. Thus, in accordance with these texts, the framework of paradox averts any alignment that could substantiate the experiences of the abused ${ }^{*}$ and could justify their queer desires, given enough time or exposure to them.

The productive and delicate framework of paradox in the evangelical sex manuals is also spiritually significant. The dual processes of self-empowerment and selfmarginalization are magnified by appeals to the ultimate authority of God. Authority from God is invested in godly leaders, the reader is assured. In Every Young Man's Battle, the authors put it this way: "You can trust us when we tell you there's a way out. You do have a choice, and that choice will lead you to what God wants for you and to the relationships He has prepared for you" (ibid., p. 227). The framework of paradox, therefore, is said to rest on a godly foundation. The question of spiritual trustworthiness appears also in Every Young Woman's Battle. The authors reveal, "When you have a personal relationship with Jesus Christ, you have His power available to you to help you resist any temptation and make whatever changes you need to make in order to pursue a lifestyle of sexual and emotional integrity. Also know that we are cheering you on and praying for you as you

24 Both texts include the phone numbers and websites for Exodus International, the now-defunct foremost ex-gay Christian ministry that shuttered in 2013; for more on Exodus International and ex-gay ministries, see (Gerber 2008). 
seek the healthy relationships God intends for you to enjoy" (Arterburn and Ethridge 2004, p. 221). That is to say, the godly authority of the authors is true and comforting because the authors are simply communicating here what God actually and obviously wants when it comes to sexual integrity.

The authors of these US evangelical sex manuals are insistent that persons with queer desires can trust in God and in godly authorities to help them deal with their abuse*. Godly authorities can be trusted if and only if they act as an extension of the reliable, plain, and inerrant text of Scripture. As the authors affirm, the trustworthiness of the Bible as the unerring and manifest Word of God ensures the godly foundation of the paradoxical framework captured in their texts. The authors dispense authority from God by appealing to Biblical passages in a fairly typical fashion for this evangelical genre. Readers can rest assured that what is commended comes straight from Scripture. The authors press their readers to independently verify their trustworthiness by consulting the infallible authority of the Bible on the matter of homosexuality and sexual morality.

To be sure, the appeal to the authority of the Bible as the Word of God is highly interpreted. It is an editorialized appeal by the authors that conforms to predominate American evangelical assumptions about the Bible, literalism, the reliability and power of Scripture, and the everyday task of interpreting the Word of God. For instance, the authors of Every Young Woman's Battle attest, "In case you question how God feels about homosexual relations, simply read the first chapter of Romans .... Although God hates the sin of homosexuality, just as He hates all sin, He passionately and unconditionally loves all sinners regardless of the sexual battles we face" (ibid., p. 220). Readers are told that they can trust the godly authority of the evangelical sex manuals in "The Every Man Series," including its treatment of queer sexuality, because the American evangelical authors are in agreement with the Bible. As interpreted by the authors, the Bible is clear: God hates homosexuality. Ergo, readers can trust the paradoxical framework of centering and decentering the victim of abuse* as advocated by the authors for the sake of spiritual healing, sexual transformation, and the redemption of abuse*.

The paradoxical framework is productive, delicate, spiritual, and, lastly, affective. As indicated by the American evangelical sex manuals, the dual processes of self-empowerment and self-marginalization (or self-annihilation) may feel disorienting, numbing, or excruciating for the reader who undergoes them. God, the Bible, and godly authorities hate the sin that the sinner (here, the homosexual victim of abuse*) ought to also hate about themselves. As suggested by the preceding passage from Every Young Woman's Battle, the severity of this hatred should be interpreted as love. As the slogan goes, "love the sinner, hate the sin." Indeed, the sinner-homosexual victim of abuse* should love themselves by hating themselves in an unceasing spiral of paradox. After all, "God will certainly honor the sacrifices you make for the sake of righteousness" (ibid., p. 221). Following the evangelical sex manuals of "The Every Man Series," persons with queer desires are both loved and hated by God and the people of God. It is so, precisely because they are-and are made to be-their own abuse*.

\subsection{Upholding and Repudiating the Paradox of Queer Abuse*}

In light of diverse applications of the American evangelical purity culture texts, no doubt some victims of abuse ${ }^{*}$ (i.e., some evangelical queers) do discover new realities about themselves by following the regimented therapeutic pathway outlined above. For these readers of Every Young Man's Battle or Every Young Woman's Battle, the regulated journey of desire work is interpreted as a restless mission, even if the destination is always already deferred on this side of eternity. These victims of abuse* perceive the programmatic pathway of healing and resilience to be a truly positive, life-giving vocation.

On the other hand, the eradication of queer desire does not comport with the experiences of many readers of US evangelical sex manuals, whether from "The Every Man Series" or from other purity culture authors like those mentioned previously. In light of these readers' application, the vast majority of abuse* victims (i.e., the remainder of evan- 
gelical and ex-vangelical queers) would not describe the schematized pathway outlined in these texts as "healing." Far more likely, these victims of abuse* would describe their experiences of desire work as traumatizing, or trauma compounded by trauma. ${ }^{25}$ For these readers, the regulated journey of self-discovery is submerged in spiritual injury. The trauma is compounded precisely because this latter cohort of abuse* victims did attempt to follow the putative journey of transformation, healing, and restoration extolled by these evangelical sex manuals with scrupulous discipline, until they finally broke. ${ }^{26}$

For both sets of readers who apply the messages from these sex manuals, abuse* is the crux of the story. Whether beneficial or detrimental, abuse* colors any discovery of one's personhood, including one's sexuality or identity, according to the texts. The victims of abuse $^{*}$ who remain within the story narrated by these sex manuals regard the journey as redemptive; but, the victims of abuse* who exit the story regard it as traumatic.

\section{Conclusions}

Scholars of religion tend to conceptualize abuse in predominately negative terms, just as most survivors do. However, the divergent pathways outlined in this essay pose a relevant question: is this the only useful analytical lens at the disposal of the scholar? Are there other ways the scholar of religion may diagram and dissect the framework of abuse within religious communities? I have argued that US evangelicalism—and specifically evangelical discourse directed at LGBTQ persons of faith - offers scholars an opportunity to reflect upon this question by distinguishing abuse from abuse* ${ }^{*}$ As I have shown, US evangelical Christians have long advocated for an alternative construction of abuse* that is no less worthy of scholarly attention, if sometimes difficult to uncover through its discrete construction, utilization, and sublimation within the evangelical subculture. In other words, American evangelicalism presents an interesting test case for the scholar of religion due to the community's repositioning of abuse* in positive terminology for the assemblage of identity, sexuality, community fellowship, and spiritual vocation.

In my examination of Every Young Man's Battle and Every Young Woman's Battle, I have shown how the "problem" of queerness is structurally differentiated as a specialized discourse in American evangelicalism. The segmentation and maintenance of purity culture theology, as well as the heteronormativity refracted throughout US evangelicalism, perpetuate the underside of the dominant narrative. Recognizing this dynamic corrects the tendency of insiders and outsiders to ignore the story of abuse* and queerness in US evangelicalism. The fusion of queerness to abuse* as a necessary starting point for the positive construction and performance of life in a religious community is notable. That some queers, despite the spiritual utilitarianism of abuse*, found their own way in the fog of this evangelical mythology is also worth mentioning. This is especially true because, as Steven Tracy and Andy Maurer have documented, "Evangelicals shows a propensity to greatly underestimate rates of physical and sexual abuse, particularly in their own congregations." ${ }^{28}$ To recognize and reckon with the evangelical mythology of abuse*, I would contend, is to be dis-abused.

Funding: This research received no external funding.

Institutional Review Board Statement: Not Applicable.

Informed Consent Statement: Not Applicable.

Data Availability Statement: Not Applicable.

Conflicts of Interest: The author declares no conflict of interest.

25 Although anecdotal, Gerrard Conley's Boy Erased and "UnErased" podcast depict the distressing levels of depression, self-harm, and suicidality that correlate to formal and informal conversion therapy tactics, and they point to the reasons why the American Psychiatric Association and many state governments in the US have condemned reparative therapy practices; Conley, Boy Erased: A Memoir of Identity, Faith, and Family (NY: Riverhead Books, 2016). see (Conley 2016, 2018).

26 I am indebted to Teresa Pasquale for this notion of "spiritual injury," or "sacred wounds," in the context of religious trauma; see (Pasquale 2015).

28 (Tracy and Maurer 2019, p. 10). 


\section{References}

Arterburn, Stephen. 2003. Every Young Man's Battle: DVD; 90 Minutes. Guardian Studies. Available online: https://fredstoeker.com/ products / every-young-mans-battle-dvd (accessed on 1 December 2020).

Arterburn, Stephen, and Fred Stoeker. 2002. Every Young Man's Battle: Strategies for Victory in the Real World of Sexual Temptation. Colorado Springs: WaterBrook Press.

Arterburn, Stephen, and Shannon Ethridge. 2004. Every Young Woman's Battle: Guarding Your Mind, Heart, and Body in a Sex-Saturated World. Colorado Springs: WaterBrook Press.

Ault, Nicole. 2019. The SBC Has a Sex-Abuse Problem. WSJ, December 26. Available online: https://www.wsj.com/articles/the-sbchas-a-sex-abuse-problem-11577400072 (accessed on 1 December 2020).

Bailey, Sarah Pulliam. 2014. Megachurch Pastors Leave Reformed Evangelical Network amid Child Abuse Scandal. Religion News Service. May 18. Available online: https:/ / religionnews.com/2014/05/18/megachurch-pastors-leave-reformed-evangelicalnetwork-amid-child-abuse-scandal/ (accessed on 1 December 2020).

CNN. 2018. Read Rachael Denhollander's Full Impact Statement about Larry Nassar. CNN, January 30. Available online: https: //www.cnn.com/2018/01/24/us/rachael-denhollander-full-statement/index.html (accessed on 1 December 2020).

Colwell, Kelly, and Sheryl Johnson. 2020. \#MeToo and \#ChurchToo: Putting the Movements in Context. Review and Expositor 117: 183-98.

Conley, Gerard. 2016. Boy Erased: A Memoir of Identity, Faith, and Family. New York: Riverhead Books.

Conley, Gerard. 2018. UnErased: The History of Conversion Therapy in America. Podcast Series. Available online: https://podcasts. apple.com/us/podcast/unerased-first-listen/id1439513792?i=1000422138028\&mt=2 (accessed on 1 December 2020).

Denhollander, Rachael. 2019. What is a Girl Worth?: A Conversation with Rachael Denhollander and Russell Moore on the Church's Abuse Crisis. Vimeo: ERLC, October 8. Available online: https://vimeo.com/365072432 (accessed on 1 December 2020).

DeRogatis, Amy. 2015. Saving Sex: Sexuality and Salvation in American Evangelicalism. New York: Oxford University Press.

Dobson, James. 2001. Bringing Up Boys: Practical Advice and Encouragement for Those Shaping the Next Generation of Men. Carol Stream: Tyndale Publishing.

Dobson, James. 2010. Bringing Up Girls: Practical Advice and Encouragement for Those Shaping the Next Generation of Women. Carol Stream: Tyndale Publishing.

Eldridge, John. 2001. Wild at Heart: Discovering the Secret of a Man's Soul. Nashville: Thomas Nelson.

Eldridge, John, and Stasi Eldridge. 2005. Captivating: Unveiling the Mystery of a Woman's Soul. Nashville: Thomas Nelson.

Frawley-O'Dea, Mary Gail. 2007. Perversion of Power: Sexual Abuse in the Catholic Church. Nashville: Vanderbilt University Press.

Gagnon, Robert. 2001. The Bible and Homosexual Practice: Texts and Hermeneutics. Nashville: Abingdon Press.

Gardner, Christine. 2011. Making Chastity Sexy: The Rhetoric of Evangelical Abstinence Campaigns. Berkeley and Los Angeles: University of California Press.

Gerber, Lynn. 2008. The Opposite of Gay: Nature, Creation, and Queerish Ex-gay Experiments. Nova Religio 11: 8-30. [CrossRef]

Gerson, Michael. 2018. Evangelicals Are Having Their Own \#MeToo Moment. Washington Post, May 7. Available online: https:/ / www.washingtonpost.com/opinions/evangelicals-are-having-their-own-metoo-moment/2018/05/07/e97be51e-52 19-11e8-a551-5b648abe29ef_story.html (accessed on 1 December 2020).

Griffith, R. Marie. 2000. God's Daughters: Evangelical Women and the Power of Submission. Berkeley and Los Angeles: University of California Press.

Griswold, Eliza. 2018. Silence Is Not Spiritual: The Evangelical \#MeToo Movement. New Yorker, June 15. Available online: https: //www.newyorker.com/news/on-religion/silence-is-not-spiritual-the-evangelical-metoo-movement (accessed on 1 December 2020).

Hackman, Melissa. 2018. Desire Work: Ex-Gay and Pentecostal Masculinity in South Africa. Durham: Duke University Press.

Immanuel Baptist. 2018. Our Pastor's Statement to the Washington Post. Immanuel Baptist, May 31. Available online: https:// immanuelky.org/articles/we-were-rachaels-church/ (accessed on 1 December 2020).

Johnson, Emily Suzanne. 2019. This Is Our Message: Women's Leadership in the New Christian Right. New York: Oxford University Press.

Johnston, Lori. 2018. This Former Gymnast Raised an Army to Take on Larry Nassar. Can She Take on Sex Abuse in Churches Now? Washington Post, February 15. Available online: https://www.washingtonpost.com/news/acts-of-faith/wp/2018/02/15 /this-former-gymnast-raised-an-army-to-take-on-larry-nassar-can-she-take-on-sex-abuse-in-churches-next/ (accessed on 1 December 2020).

Jones, Serene. 2009. Trauma and Grace: Theology in a Ruptured World. Louisville: Westminster John Knox Press.

Keller, Timothy, and Kathy Keller. 2011. The Meaning of Marriage: Facing the Complexities of Commitment with the Wisdom of God. New York: Riverhead Books.

Lee, Morgan. 2018. My Larry Nassar Testimony Went Viral. But There's More to the Gospel Than Forgiveness. Christianity Today, January 31. Available online: https://www.christianitytoday.com/ct/2018/january-web-only/rachael-denhollander-larrynassar-forgiveness-gospel.html (accessed on 1 December 2020).

Levenson, Eric. 2018. Larry Nassar Sentenced to up to 175 Years in Prison for Decades of Sexual Abuse. CNN, January 24. Available online: https://www.cnn.com/2018/01/24/us/larry-nassar-sentencing/index.html (accessed on 1 December 2020).

Macur, Juliet. 2018. In Larry Nassar's Case, A Single Voice Eventually Raised an Army. NYT, January 24 . Available online: https:/ / nyti.ms /2FaK2Mk (accessed on 1 December 2020). 
Moore, Beth. 2018. A Letter to My Brothers. The LPM Blog, May 3. Available online: https:/ /blog.lproof.org/2018/05/a-letter-to-mybrothers.html (accessed on 1 December 2020).

Morse, Dan. 2014. Child Sex Abuser from Gaithersburg-area Sentenced to 40 Years in Prison. Washington Post, August 14. Available online: https:/ / www.washingtonpost.com/local/crime/child-sex-abuser-from-gaithersburg-area-church-to-be-sentencedon-thursday/2014/08/13/4fc244ca-235d-11e4-958c-268a320a60ce_story.html (accessed on 1 December 2020).

Moslener, Sara. 2015. Virgin Nation: Sexual Purity and American Adolescence. New York: Oxford University Press.

Pasquale, Teresa. 2015. Sacred Wounds: A Path to Healing from Spiritual Trauma. St. Louis: Chalice Press.

Pearse, Joshua. 2018. The Sin of Silence: The Epidemic of Denial about Sexual Abuse in the Evangelical Church. Washington Post, May 31. Available online: https://www.washingtonpost.com/news/posteverything/wp/2018/05/31/feature/the-epidemic-ofdenial-about-sexual-abuse-in-the-evangelical-church/ (accessed on 1 December 2020).

Piper, John, and Wayne Grudem. 1991. Recovering Biblical Manhood and Womanhood: A Response to Evangelical Feminism. Wheaton: Crossway.

Raisman, Aly. 2018. Rachael Denhollander: Time 100 Most Influential People of 2018. Time. Available online: https://time.com/ collection/most-influential-people-2018/5217581/rachael-denhollander/ (accessed on 1 December 2020).

Rambo, Shelly. 2010. Spirit and Trauma: A Theology of Remaining. Louisville: WJK Press.

Relevant Staff. 2019. Andy Savage is Planting a New Church Following Resignation Over Sex Abuse. Relevant Magazine, October 30. Available online: https://relevantmagazine.com/current/andy-savage-is-planting-a-new-church-following-resignation-oversex-abuse/ (accessed on 1 December 2020).

Rogers, Jack. 2006. Jesus, The Bible, and Homosexuality: Explode the Myths, Heal the Church. Louisville: WJK Press.

Satinover, Jeffrey. 1996. Homosexuality and the Politics of Truth. Grand Rapids: Baker.

Shellnutt, Kate. 2018a. C.J. Mahaney Withdraws from T4G. Christianity Today, March 7. Available online: https:/ / www.christianitytoday. com/news/2018/march/cj-mahaney-withdraws-t4g-conference-sgm-rachael-denhollande.html (accessed on 1 December 2020).

Shellnutt, Kate. 2018b. Divorce after Abuse: How Paige Patterson's Counsel Compares to Other Pastors. Christianity Today, April 30. Available online: https://www.christianitytoday.com/news/2018/april/paige-patterson-divorce-domestic-abuse-swbtscbmw.html (accessed on 1 December 2020).

Shellnutt, Kate. 2018c. Paige Patterson Fired by Southwestern, Stripped of Retirement Benefits. Christianity Today, May 30. Available online: https:/ / www.christianitytoday.com/news/2018/may/paige-patterson-fired-southwestern-baptist-seminary-sbc.html (accessed on 1 December 2020).

Shellnutt, Kate. 2019. 10 Women Who Are Changing the Southern Baptist Response to Abuse. Christianity Today, May 17. Available online: https:/ / www.christianitytoday.com/ct/2019/june/sbc-abuse-survivors-advocates-profiles.html (accessed on 1 December 2020).

Smietana, Bob. 2018a. Bill Hybels Accused of Sexual Misconduct by Former Willow Creek Leaders. Christianity Today, March 22. Available online: https:/ / www.christianitytoday.com/news/2018/march/bill-hybels-misconduct-willow-creek-john-nancyortberg.html (accessed on 1 December 2020).

Smietana, Bob. 2018b. Bill Hybels Resigns from Willow Creek. Christianity Today, April 10. Available online: https://www. christianitytoday.com/news/2018/april/bill-hybels-resigns-willow-creek-misconduct-allegations.html (accessed on 1 December 2020).

Smietana, Bob. 2018c. The \#MeToo Movement Has Educated Pastors. And Left Them with More Questions. Christianity Today, September 18. Available online: https:/ / www.christianitytoday.com/news/2018/september/metoo-domestic-violence-sexualabuse-pastors-lifeway-2018.html (accessed on 1 December 2020).

Smietana, Bob. 2018d. Willow Creek Promises Investigations Amid New Allegations Against Bill Hybels. Christianity Today, April 21. Available online: https://www.christianitytoday.com/news/2018/april/bill-hybels-willow-creek-promises-investigationallegations.html (accessed on 1 December 2020).

Sovereign Grace. 2019. Allegations against Sovereign Grace Churches. April 12. Available online: https://sovereigngrace.com/faq/ (accessed on 1 December 2020).

Stanley, Tiffany. 2016. The Sex-Abuse Scandal That Devastated a Suburban Megachurch: Inside the Rise and Fall of Sovereign Grace Ministries. Washingtonian, February 14. Available online: https://www.washingtonian.com/2016/02/14/the-sex-abuse-scandalthat-devastated-a-suburban-megachurch-sovereign-grace-ministries / (accessed on 1 December 2020).

Stetzer, Ed. 2018. Andy Savage's Standing Ovation Was Heard Round the World. Because It Was Wrong. Christianity Today, January 11. Available online: https:/ / www.christianitytoday.com/edstetzer/2018/january / andy-savages-standing-ovation-was-heardround-world-because.html (accessed on 1 December 2020).

Strader, Kelly, Molly Selvin, and Lindsey Hay. 2015. Gay Panic, Gay Victims, and the Case for Gay Shield Laws. Cardozo Law Review 36: 1473-531.

Strassfeld, Max. 2018. Toward a Transfeminist Religious Studies: Transing Religious Studies. Journal of Feminist Studies in Religion 34: 37-53. [CrossRef]

Tedesco, John, Lise Olsen, Robert Downen, and Sarah Smith. 2019. Abuse of Faith: A Chronicle Investigation, Part 1-6. Houston Chronicle, February 10, 12, \& 13, May 31, and June 3 \& 6. Available online: https://www.houstonchronicle.com/local/investigations/ abuse-of-faith/?mod=article_inline (accessed on 1 December 2020).

Tonstad, Linn Marie. 2018. Queer Theology: Beyond Apologetics. Eugene: Cascade. 
Tracy, Steven R., and Andy Maurer. 2019. \#MeToo and Evangelicalism: Shattering Myths about Sexual Abuse and Power. Cultural Encounters 14: 3-21.

Viefhues-Bailey, Ludger H. 2010. Between a Man and a Woman?: Why Conservatives Oppose Same-Sex Marriage. New York: Columbia University Press.

Warner, Megan, Christopher Southgate, Carla Grosch-Miller, and Hilary Ison. 2019. Tragedies and Christian Congregations: The Practical Theology of Trauma. New York: Routledge.

White, Heather. 2015. Reforming Sodom: Protestants and the Rise of Gay Rights. Chapel-Hill: UNC Press.

Woodson, Jules. 2018. I was Assaulted. He was Applauded. NYT, March 9. Available online: https://www.nytimes.com/2018/03/09 /opinion/jules-woodson-andy-savage-assault.html (accessed on 1 December 2020). 